\title{
Pola Kemitraan Yayasan Trikaya dalam Pengembangan Usahatani Padi Organik di Subak Purnajaya, Desa Lebih, Kecamatan Gianyar, Kabupaten Gianyar
}

\author{
ANAK AGUNG RISKHA ANINDITA, I WAYAN BUDIASA, \\ I G A A LIES ANGGRENI
}

Program Studi Agribisnis Fakultas Pertanian Universitas Udayana

Jl. PB. Sudirman Denpasar 80232

Email: riskhaanindita@yahoo.co.id

wba.agr@unud.ac.id

\begin{abstract}
Trikaya Foundation Partnership Pattern in the Development of Organic Rice Farming in Subak Purnajaya, Lebih Village, Gianyar Sub-District, Gianyar Regency
\end{abstract}

Rice as one of agriculture's mainstay commodities in Gianyar Regency whichhas big opportunity, but Subak Purnajaya in the Lebih Village only able to produce an average of 2.5 up to 3 tons/ha with conventional farming systems and do not get market guarantee. Seeing these conditions, the Trikaya Foundation created an organic rice pilot project by embracing farmers to be its partners. This study aims to: (1) Analyze the characteristics of Subak Purnajaya before the partnership is implemented; (2) Analyze the pattern and mechanism of partnership that is applied; (3) Analyze the obstacles faced in realizing the sustainability of partnerships between the foundation and subaks. The analytical method used was qualitative and quantitative descriptive analysis. The results of the study showed that (1) The characteristics of Subak Purnajaya before the partnership was implemented, namely the limited knowledge possessed by farmers and the subak was still applying conventional farming systems; (2) The partnership implemented in the Subak Purnajaya was a pattern of Agribusiness Operation Partnership; (3) The foundation constraints had not optimally accommodated farmers production and limited infrastructure facilities, while the constraints of farmers found it difficult to find harvesters during great harvest time and are still dependent on the foundation. Based on the results of the research, the foundation should be able to utilize the role of social media to reach a wider market segments and improve the management system in establishing partnerships, while farmers continue practicing organic farming because it is more profitable than the conventional systems.

Keywords: partnership, organic rice, subak, Trikaya Foundation

\section{Pendahuluan}

1.1 Latar Belakang

Padi merupakan tanaman pangan sekaligus penghasil beras yang menjadi bahan makanan pokok. Pemenuhan kebutuhan akan beras ini dapat terealisasi melalui 
pembangunan pertanian.Provinsi Bali memiliki lima kabupaten penghasil padi yaitu Kabupaten Tabanan, Gianyar, Badung, Karangasem, dan Buleleng. Kabupaten Gianyar merupakan salah satu kabupaten di Provinsi Bali yang dikenal sebagai penghasil padi tertinggi setelah Kabupaten Tabanan. Terlihat dari kontribusi produksipadi per kabupaten/kota, produksi padi di Kabupaten Gianyar pada tahun 2017 mencapai 184.592 ton dengan luas panen 31.090 ha, sedangkan produksi padi di Kabupaten Tabanan yaitu 233.681 ton dengan luas panen 41.611 ha(BPS Provinsi Bali, 2017).

Berbagai kebijakan telah dilakukan pemerintah dalam upaya untuk meningkatkan produksi pertanian, salah satu kebijakan subsidi input produksi adalah kebijakan subsidi pupuk yaitu pupuk organik dan pupuk kimia (anorganik). Program subsidi pupuk organik oleh Pemerintah Provinsi Bali ini merupakan salah satu upaya menjadikan Bali sebagai pulau organik, namun penerapan penggunaan pupuk organik secara penuh saat ini masih belum terlaksana (Dinas Pertanian Provinsi Bali, 2013). Kerjasama dalam bentuk kemitraan antara petani dengan suatu lembaga yang dapat membantu petani dalam penyediaan sarana dan prasarana serta pemasaran hasil produksi dilakukanuntuk memotivasi petani agar menerapkan pertanian organik khususnya padi. Subak yang yang menjalin kemitraan dengan lembaga sosial yaitu Subak Purnajaya yang berlokasi di Desa Lebih yang bermitra dengan Yayasan Trikaya. Menurut BPS (2014), total luas lahan padi yang tersedia 13,4 juta ha dengan produktivitas nasional 5,42 ton/ha, namun Subak Purnajaya hanya mampu menghasilkan rata-rata 2,5 s.d 3 ton/ha dengan menerapkan sistem pertanian konvensional dan tidak mendapatkan jaminan pasar.

Melihat kondisi tersebut, yayasan membuat proyek percontohan padi organik dengan merangkul petani untuk bermitra dalam mengembangkan pertanian organik dan ingin membuktikan bahwa dengan pertanian organik dapat membantu meningkatkan pendapatan petani dan hasil produksi khususnya padi. Maka perlu dilakukan penelitian untuk mengetahui karakteristik Subak Purnajaya sebelum kemitraan, pola dan mekanisme kemitraan yang diterapkan di kedua subak, serta kendala-kendala yang dihadapi dalam mewujudkan keberlanjutan kemitraan antara yayasan dan subak.

\subsection{Rumusan Masalah}

Permasalahan pokok dalam penelitian ini dapat dirumuskan sebagai berikut.

1. Bagaimana karakteristik Subak Purnajaya, Desa Lebih, Kecamatan Gianyar, Kabupaten Gianyar sebelum dilaksanakan kemitraan?

2. Bagaimana pola dan mekanisme kemitraan yang diterapkan dalam pengembangan dan peningkatan produktivitas serta pemasaran hasil pertanian di Subak Purnajaya, Desa Lebih, Kecamatan Gianyar, Kabupaten Gianyar ?

3. Apa kendala-kendala yang dihadapi dalam mewujudkan keberlanjutan kemitraan antara Yayasan Trikaya dengan Subak Purnajaya, Desa Lebih, Kecamatan Gianyar, Kabupaten Gianyar?

\subsection{Tujuan Penelitian}

Tujuan penelitian ini adalah sebagai berikut.

1. Menganalisis karakteristik Subak Purnajaya, Desa Lebih, Kecamatan Gianyar, Kabupaten Gianyar sebelum dilaksanakan kemitraan.

2. Menganalisis pola dan mekanisme kemitraan yang diterapkan dalam pengembangan dan peningkatan produktivitas serta pemasaran hasil pertanian di Subak Purnajaya, Desa Lebih, Kecamatan Gianyar, Kabupaten Gianyar. 
3. Menganalisis kendala-kendala yang dihadapi dalam mewujudkan keberlanjutan kemitraan antara Yayasan Trikaya dengan Subak Purnajaya, Desa Lebih, Kecamatan Gianyar, Kabupaten Gianyar.

\section{Metode Penelitian}

\subsection{Lokasi dan Waktu Penelitian}

Penelitian ini dilaksanakan di Subak Purnajaya, Desa Lebih, Kecamatan Gianyar, Kabupaten Gianyar. Pemilihan lokasi dilakukan secara sengaja(purposive sampling), dengan pertimbanganSubak Purnajaya adalah subak yang dijadikan proyek percontohan di Desa Lebih dan didampingi secara aktif oleh Yayasan Trikaya terkait dalam pengembangan usahatani padi organik sejak tahun 2012. Waktu penelitian dilakukan selama lima bulan yaitu mulaiJanuari 2018 sampai dengan Mei 2018.

\subsection{Jenis dan Sumber Data Penelitian}

Data yang digunakan dalam penelitian ini adalah data kualitatif dan data kuantitatif. Data kualitatif, yaitu suatu prosedur penelitian yang menggunakan data deskriptif berupa kata-kata tertulis atau lisan yang berhubungan dengan objek penelitian (Antara, 2004), data ini digunakan untuk menganalisis karakteristik subak, pola dan mekanisme kemitraan, serta kendala-kendala yang dihadapi dalam mewujudkan keberlanjutan kemitraan.Data kuantitatif, yaitu kegiatan analisis data meliputi pengolahan dan penyajian data dalam bentuk angka yang dapat dihitung, data ini diperoleh melalui data yang terkumpul dari hasil survey di lapangan (Antara, 2004). Data kuantitatif digunakan untuk menghitung jumlah petani subak, data luasan lahan subak, dan pendapatan petani.

Sumber data penelitian ini adalah data primer yaitu data penelitian yang diperoleh secara langsung dari sumber pertama atau tempat objek penelitian dilakukan dan data sekunder yaitu data yang diperoleh dari teknik pengumpulan data yang menunjang data primer (Ibrahim, 2015)

\subsection{Metode Pengumpulan Data}

Metode pengumpulan data yang digunakan pada penelitian ini adalah metode survey usahatani danwawancara mendalam melalui bantuan kuesioner dan pedoman wawancara.

\subsection{Populasi, Responden, dan Informan Kunci}

Populasi dalam penelitian ini berjumlah 70 orang petani yang seluruhnya merupakan anggota aktif. Teknik pengambilan sampel menggunakan simple random sampling karena anggota populasi bersifat homogen, responden yang dipilih yaitu kepala keluarga dengan pengambilan ukuran sampel terkecil yang dapat diterima untuk penelitian deskriptif adalah minimal $10 \%$ dari populasi(Sumanto, 1990)maka sampel yang diambil sebanyak $43 \%$ yaitu terdiri atas 30 orang petani. Informan kunci dalam penelitian ini berjumlah dua orang yaitu I Wayan Jara selaku Pekaseh Subak Purnajaya dan I Gusti Ayu Putu Erawati, BA, S.Sos selaku ketua pengurus Yayasan Trikaya.

\subsection{Variabel dan Analisis Data}


Variabel-variabel yang dianalisis dalam penelitian ini adalah (1) Karakteristik subak; (2) Pola kemitraan; (3) Kendala-kendala. Variabel-variabel dalam penelitian ini akan dianalisis dengan metode analisis deskriptif kualitatif dan analisis kuantitatif.

\section{Hasil dan Pembahasan}

\subsection{Karakteristik Subak Purnajaya}

Karakteristik subak untuk mengetahuibagaimana kondisi dan apa yang menjadi kekurangan subak sebelum kemitraan. Karakteristik Subak Purnajaya dikaji melalui konsep Tri Hita Karana (tiga unsur yang menyebabkan kebahagiaan). Menurut Sutawan, dkk (dalam Windia, 2006) tiga unsur yang terdapat dalam Tri Hita Karana pada hakikatnya terdiri atas parhyangan,pawongan, dan palemahan.

\subsubsection{Aspek parhyangan}

Aspek parhyangan merupakan wujud keserasian hubungan antara manusia dengan pencipta-Nya yakni Tuhan Yang Maha Esa. Hal ini diimplementasikan melalui adanya bangunan suci subak dan ritual yang mengikutinya di lahan persawahan.

1. Keberadaan pura

Subak Purnajaya memiliki dua bangunan pura yaitu Pura Ulun Swi (Pura Empelan) pura yang berada di lokasi bangunan bendung yang terletak di Banjar Kesian, pura ini dimanfaatkan sebagai tempat pelaksanaan upacara magpag toya(menjemput air dari sumber mata air)dan Pura Bedugul sebagai tempat pemujaan Dewi Sri yang terletak di Desa Lebih. Anggota subak rutin melaksanakan upacara yadnya di kedua pura tersebut yang dilaksanakan setiap setahun sekali. Selain melaksanakan upacara di Pura Ulun Swi dan Pura Bedugul, petani Subak Purnajaya juga rutin melaksakan upacara yadnya di Pura Ulun Danu yang terletak di Batur. Setiap dilaksanakan odalan atau upacara yadnya di Pura Batur, Subak Purnajaya dikenakan iuran (membayar emping)sebesar Rp. 700.000 setiap tahunnya. Hal tersebut terlihat bahwa adanya hubungan yang kuat antara kondisi pura dengan kinerja pengelolaan subak yang bersangkutan.

2. Keberadaan Sanggah Catu

Sanggah Catu (tidak terbentuk secara permanen) merupakan pura milik perseorangan dan tidak semua anggota subak memiliki Sanggah Catu. Upacara yang dilakukan di Sanggah Catu tergantung pada perhatian anggota subak itu sendiri untuk melaksanakan upacara yadnya, sehingga tidak dilaksanakan secara bersamaan.

\subsubsection{Aspek pawongan}

Aspek pawongan artinya membentuk keharmonisan dengan sesamanya, yakni melakukan koordinasi atau hubungan dengan organisasi atau masyarakat sekitarnya. Hal tersebut ditunjukkan oleh adanya organisasi petani yang disesuaikan dengan kebutuhan subak dan disesuaikan pula dengan tujuan-tujuan yang ingin dicapai, selain itu dilihat dari keaktifan anggota subak dalam mengikuti kegiatan rapat, dan penerapan awigawig/pararem serta sanksi yang telah ditetapkan.

1. Struktur organisasi Subak Purnajaya

Subak Purnajaya memiliki struktur organisasi yang cukup sederhana, yaitu terdiri dari ketua/kelian subak (pekaseh), penyarikan (sekretaris), patengen (bendahara), petajuh, ksinoman (juru arah), dan anggota. Subak Purnajaya dipimpin oleh ketua I Wayan Jara yang memiliki tugas untuk mengatur air irigasi serta perbaikan irigasi, sebagai jembatan untuk kepentingan pemerintah dengan petani, mengatur upacara- 
upacara di pura, memimpin rapat-rapat anggota dan kegiatan gotong royong. Bendahara yaitu Mangku Wala yang bertugas sebagai pengelola keuangan. Sekretaris yaitu I Ketut Suganda bertugas sebagai pengatur di bagian administrasi dan rapat-rapat anggota. Petajuh bertugas untuk membantu pekaseh dalam pembagian air dan ksinoman bertugas sebagai juru arah. Saat ini posisi petajuh dan ksinoman di Subak Purnajaya belum ada yang menduduki, sehingga tugas dan tanggungjawab petajuh dan ksinoman diambil alih oleh pekaseh subak. Subak Purnajaya memiliki anggota sebanyak 70 orang dan seluruhnya merupakan anggota aktif.

2. Keaktifan anggota subak dalam megikuti kegiatan rapat

Anggota Subak Purnajaya rutin mengadakan kegiatan rapat yang dilaksanakan pada saat tumpek/Sabtu Kliwon atau setiap 35 hari sekali tepatnya dilaksanakan pada hari Kamis, dikarenakan hari tersebut dipercaya sebagai hari untuk beristirahat bagi anggota subak artinya seluruh anggota subak tidak melakukan aktivitas di sawah. Jika ada anggota subak yang tidak menghadiri rapat maupun gotong royong maka diberikan sanksi berupa denda sebesar Rp. 5.000,00 setiap satu kali ketidakhadiran. Melalui kegiatan rapat ini petani dapat berinteraksi dengan mitra kerjanya terkait dengan cara pola berocok tanam, dosis pemberian pupuk, dan petani dapat menyampaikan permasalahan-permasalahan yang terjadi di lapangan, sehingga melalui kegiatan rapat dapat mempermudah proses kemitraan.

3. Penerapan awig-awig, pararem, dan sanksi

Subak Purnajaya memiliki aturan tertulis berupa awig-awig dan pararem yang umumnya sangat ditaati pelaksanaannya oleh anggota subak. Awig-awig dan pararem merupakan kontrol sosial, artinya alat pengatur anggota subak agar berperilaku sesuai dengan ketentuan. Aturan-aturan tersebut berisi mengenai hal-hal yang berkaitan dengan tujuan subak, yaitu dapat mengelola sistem irigasi berdasarkan harmoni dan kebersamaan.Anggota atau krama subak tidak ada yang berani melanggar awig-awig dan pararem mengingat adanya sanksi sosial yang ditetapkan. Jika anggota subak mencuri air di sawah dikenai denda sesuai ketentuan subak. Denda-denda dalam pelanggaran diputuskan sesuai hasil musyawarah.

\subsubsection{Aspek palemahan}

Aspek palemahan merupakan keharmonisan hubungan antara manusia dengan alam, yang dimanifestasikan dalam wilayah atau lahan pertanian yang menjadi wilayah usahatani anggotanya. Subak Purnajaya memiliki luas areal persawahan 26 ha dengan batas-batas yaitu sebelah Utara dan Timur dibatasi oleh Subak Padang Lantang, sedangkan sebelah Selatan dan Barat dibatasi oleh Subak Juwet.

Subak Purnajaya memiliki beberapa fasilitas untuk mendukung proses kelancaran dalam melakukan usahatani di subak seperti jaringan irigasi, balai subak, koperasi, balai kulkul, dan balai timbang. Dahulu Subak Purnajaya mengalami masalah kekurangan air, sebelum menjalin kemitraan dengan yayasan, Subak Purnajaya masih menerapkan sistem pertanian konvensional dengan pola tanam padi-padi-palawija. Padi I(bulan Juni s.d September), padi II (bulan Oktober s.d Januari), sedangkan untuk palawija (bulan Februari s.d Mei). Palawija yang ditanam di Subak Purnajaya yaitu jenis kacangkacangan termasuk kedelai. Sasih yang paling cocok untuk menanam padi di Subak Purnajaya yaitu pada bulan Juni s.d Agustus. Baik dari segi hasil dapat dipastikan produksi padi lebih banyak dibandingkan pada bulan-bulan lainnya. 
Selain itu, karena faktor teknologi yang menggunakan traktor untuk mempermudah petani dalam mengolah lahan membuat pola tanam semakin ditinggalkan yang berdampak kepada derajat kemasaman tanah menjadi tinggi yaitu 4,0 yang menyebabkan penurunan ketersediaan unsur hara bagi tanaman sehingga menghambat pertumbuhan tanaman dan berdampak kepada produksi menjadi rendah.

\subsection{Pola dan Mekanisme Kemitraan}

\subsubsection{Pelaksanaan kemitraan}

Pelaksanaan kemitraan antara Yayasan Trikaya dengan petani di Subak Purnajaya sudah terjalin sejak tahun 2012. Adapun tahapan yang dilakukan dalam menjalin kemitraan sebagai berikut.

1. Yayasan Trikaya melakukan pendekatan kepada pengurus Subak Purnajaya agar bersedia bermitra.

2. Yayasan Trikaya melakukan sosialisasi kepada anggota Subak Purnajaya mengenai program proyek percontohan pertanian organik.

3. Membuat perjanjian secara bersama-sama melalui kontrak kerjasama berupa Memorandum of Understanding (MOU) antara Yayasan Trikaya dengan Subak Purnajaya yang memuat hak dan kewajiban kedua belah pihak. berikut.

Hak dan kewajiban masing-masing pihak dalam menjalin kemitraan sebagai

A. Hak dan kewajiban Yayasan Trikaya

Tabel 1.

Hak dan Kewajiban Yayasan Trikaya

\begin{tabular}{|c|c|}
\hline Hak & Kewajiban \\
\hline $\begin{array}{l}\text { 1. Yayasan Trikaya berhak untuk mendapatkan } \\
\text { produk dengan kualitas yang baik dari } \\
\text { subak. }\end{array}$ & $\begin{array}{l}\text { 1. Yayasan Trikaya berkewajiban memberikan } \\
\text { sarana produksi seperti bibit, pupuk, dan } \\
\text { obat-obatan kepada petani subak. } \\
\text { 2. Yayasan Trikaya berkewajiban memberikan } \\
\text { pembinaan dan pendampinagan kepada } \\
\text { petani subak. } \\
\text { 3. Yayasan Trikaya berkewajiban membeli dan } \\
\text { memasarkan hasil produksi dari subak. } \\
\text { 4. Yayasan Trikaya berkewajiban mematuhi } \\
\text { dan mengikuti ketentuan yang telah } \\
\text { disepakati bersama. }\end{array}$ \\
\hline
\end{tabular}

B. Hak dan kewajiban Subak Purnajaya

Tabel 2.

Hak dan Kewajiban Subak Purnajaya

\begin{tabular}{|c|c|}
\hline Hak & Kewajiban \\
\hline $\begin{array}{l}\text { 1. Subak berhak mendapatkan sarana produksi } \\
\text { seperti bibit, pupuk, dan obat-obatan dari } \\
\text { Yayasan Trikaya. } \\
\text { 2. Subak berhak mendapat pendampingan dan } \\
\text { pembinaan mengenai pertanian organik. } \\
\text { 3. Subak berhak mendapat jaminan pasar. }\end{array}$ & $\begin{array}{l}\text { 1. Subak menyediakan lahan dan tenaga } \\
\text { kerja. } \\
\text { 2. Subak berkewajiban menjual semua hasil } \\
\text { panen kepada Yayasan Trikaya. } \\
\text { 3. Subak berkewajiban mematuhi dan } \\
\text { mengikuti ketentuan yang telah disepakati } \\
\text { bersama. } \\
\text { 4. Subak berkewajiban menjaga kualitas } \\
\text { produknya. }\end{array}$ \\
\hline
\end{tabular}

Berdasarkan hak dan kewajiban antara Yayasan Trikaya dengan Subak Purnajaya, serta mekanisme kemitraaan yang dijalankan oleh kedua belah pihak, dapat disimpulkan bahwa pola kemitraan yang terjalin antara yayasan dengan subak termasuk pola 
Kerjasama Operasional Agribisnis (KOA). Menurut Sumardjo (2004) kemitraan pola Kerjasama Operasional Agribisnis (KOA), petani mitra berperan menyediakan tenaga kerja dan lahan untuk usahatani mereka, sedangkan, yayasan bertanggung jawab atas penyediaan modal usahatani berupa sarana produksi, memberikan penyuluhan serta pendampingan, membeli hasil produksi dan juga berperan untuk menjamin pemasaran hasil produksi petani.

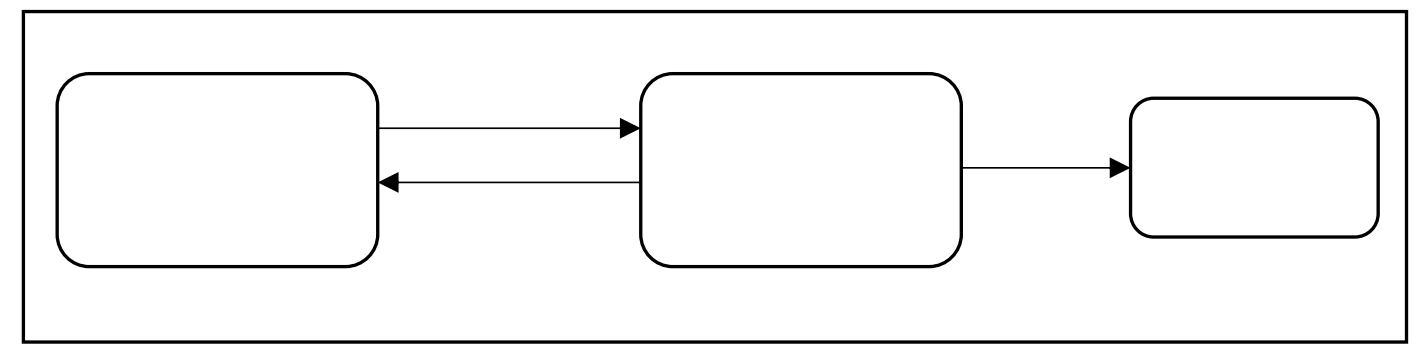

Gambar 1.Skema Kemitraan antara Yayasan Trikaya dengan Petani Subak Purnajaya

\subsubsection{Penerimaan usahatani}

Penerimaan usahatani diperoleh dari perkalian hasil produksi dengan harga produk (Widyantara, 2015).Jumlah produksi dan penerimaan yang diperoleh petani saat menggunakan sistem pertanian organik dan pada saat menggunakan sistem pertanian konvensional dalam satu hektar dapat dilihat pada Tabel 3.

Tabel 3.

Penerimaan Petani Subak Purnajaya, Desa Lebih, Kecamatan Gianyar, Kabupaten Gianyar

\begin{tabular}{ccccccc}
\hline \multirow{3}{*}{ Produksi } & \multicolumn{3}{c}{ Organik } & & \multicolumn{3}{c}{ Konvensional } \\
\cline { 2 - 7 } & $\begin{array}{c}\text { Harga } \\
(\mathrm{Rp} / \mathrm{kg})\end{array}$ & $\begin{array}{c}\text { Volume } \\
(\mathrm{kg})\end{array}$ & $\begin{array}{c}\text { Penerimaan } \\
(\mathrm{Rp})\end{array}$ & $\begin{array}{c}\text { Harga } \\
(\mathrm{Rp} / \mathrm{kg})\end{array}$ & $\begin{array}{c}\text { Volume } \\
(\mathrm{kg})\end{array}$ & $\begin{array}{c}\text { Penerimaan } \\
(\mathrm{Rp})\end{array}$ \\
\hline Jumlah & 4.200 & 8.000 & 33.600 .000 & 3.300 & 5.000 & 16.500 .000 \\
\hline
\end{tabular}

Sumber : Diolah dari data primer, 2018

Keterangan :

Sistem organik : Maret 2013 sampai dengan Februari 2014

Sistem konvensional : Maret 2016 sampai dengan Februari 2017

Produksi yang dihasilkan dalam usahatani ini yaitu berupa gabah kering panen (GKP).Pada Tabel 3 produksi padi yang dihasilkan dengan menggunakan sistem organik lebih tinggi dibandingkan dengan sistem konvensional. Pada saat menerapkan sistem organik produksi padi paling tinggi mencapai 8 ton/ha atau $8.000 \mathrm{~kg} / \mathrm{ha} \mathrm{GKP}$, namun setelah tidak didukung penuh oleh Yayasan Trikaya, petani kembali menerapkan sistem konvensional yang berdampak pula kepada penurunan produksi sampai 5 ton/ha atau $5.000 \mathrm{~kg} / \mathrm{ha} \mathrm{GKP.}$

Hasil GKP sistem organik dibayar oleh Yayasan Trikaya dengan harga Rp. $4.200 / \mathrm{kg}$ dan penerimaan yang diperoleh dari usahatani padi dengan sistem organik sebesar Rp. 33.600.000,00 per hektar, sedangkan hasil GKP sistem konvensional dibayar oleh tengkulak dengan harga $\mathrm{Rp} .3 .300 / \mathrm{kg}$ dan penerimaan yang diperoleh hanya sebesar Rp. 16.500.000,00 per hektar. Terlihat bahwa dengan perbedaan harga yang diterima artinya petani sudah mendapatkan keuntungan dengan menjual GKP dengan sistem organik, ditambah pula adanya kepastian harga dan terjaminnya pangsa pasar yang sudah diberikan oleh pihak Yayasan Trikaya. 


\subsubsection{Biaya produksi}

Biaya produksi usahatani adalah sejumlah nilai dari semua faktor produksi yang dialokasikan dalam usahatani (Widyantara, 2015). Biaya-biaya yang dikeluarkan petani dalam usahatani padi dalam satu musim tanam dapat dilihat pada Tabel 4.

\section{Tabel 4.}

Biaya Produksi Petani Subak Purnajaya, Desa Lebih, Kecamatan Gianyar, Kabupaten Gianyar

\begin{tabular}{rlrrrr}
\hline \multirow{2}{*}{ No. } & \multirow{2}{*}{ Uraian } & \multicolumn{2}{c}{ Organik } & \multicolumn{2}{c}{ Konvensional } \\
\cline { 3 - 6 } 1. & Biaya tetap & Total Biaya & $(\%)$ & Total Biaya & $(\%)$ \\
\hline & a. Biaya penyusutan & $\mathbf{3 3 0 . 4 4 8}$ & 12,44 & $\mathbf{3 3 0 . 4 4 8}$ & 11,28 \\
b. Pajak & 235.115 & & 235.115 & \\
2. & 95.333 & & 95.333 & \\
Biaya variabel & $\mathbf{2 . 3 2 6 . 5 9 2}$ & 87,56 & $\mathbf{2 . 5 9 9 . 2 8 3}$ & 88,72 \\
& a. Biaya pengolahan lahan & 713.333 & & 1.070 .000 & \\
b. Biaya tenaga kerja & 782.467 & & 814.800 & \\
c. Biaya bibit & 156.042 & & 156.933 & \\
d.Biaya pupuk & 508.383 & & 332.400 & \\
e. Biaya obat-obatan & 166.367 & & 225.150 & $\mathbf{1 0 0}$ \\
\hline
\end{tabular}

Sumber : Diolah dari data primer, 2018

Keterangan:

Luas lahan

Sistem organik $\quad$ : Maret 2013 sampai dengan Februari 2014

Sistem konvensional : Maret 2016 sampai dengan Februari 2017

Pada Tabel 4 menunjukkan bahwa rata-rata biaya produksi yang dikeluarkan oleh petani saat sistem organik adalah sebesar Rp. 2.657.040,00, sedangkan rata-rata biaya produksi pada saat menggunakan sistem konvensional sebesar Rp. 2.929.731,00 dengan luas lahan sebesar 35,67 are. Hal tersebut menunjukkan bahwa biaya produksi yang dikeluarkan oleh petani pada saat menggunakan sistem konvensional lebih tinggi dibandingkan dengan sistem organik.

\subsubsection{Pendapatan usahatani}

Pendapatan usahatani petani subak merupakan selisih antara penerimaan usahatani dengan biaya usahatani atau biaya produksi(Soekartawi, 2002). Pendapatan usahatani petani Subak Purnajaya disajikan pada Tabel 5.

Tabel 5.

Pendapatan Petani Subak Purnajaya, Desa Lebih, Kecamatan Gianyar, Kabupaten Gianyar

\begin{tabular}{clrc}
\hline \multirow{2}{*}{ No. } & \multicolumn{1}{c}{ Uraian } & Organik & Konvensional \\
\cline { 3 - 4 } & & Jumlah $(\mathrm{Rp})$ & Jumlah $(\mathrm{Rp})$ \\
\hline 1. & Penerimaan usahatani & 12.992 .000 & 6.290 .900 \\
2. & Biaya variabel & 2.326 .592 & 2.599 .283 \\
3. & Biaya tetap & 330.448 & 330.448 \\
4. & Total biaya (2+3) & 2.657 .040 & 2.929 .731 \\
\hline & Pendapatan usahatani (1-4) & $\mathbf{1 0 . 3 3 4 . 9 6 0}$ & $\mathbf{3 . 3 6 1 . 1 6 9}$ \\
\hline
\end{tabular}

Sumber : Diolah dari data primer, 2018

Keterangan:

Luas lahan

Sistem organik $\quad$ : Maret 2013 sampai dengan Februari 2014

Sistem konvensional : Maret 2016 sampai dengan Februari 2017 
Pada Tabel 5 menunjukkan bahwa rata-rata pendapatan usahatani petani Subak Purnajaya pada saat menerapkan sistem organik yaitu sebesar Rp. 10.334.960,00, sedangkan setelah tidak didukung penuh oleh yayasan dan kembali menggunakan sistem konvensional rata-rata pendapatan usahatani yang diterima hanya Rp. 3.361.169,00artinya terjadi penurunan pendapatan sebesar 50,92\%. Terlihat bahwa pendapatan yang diterima petani saat menerapkan sistem organik lebih tinggi dibandingkan dengan petani saat menerapkan sistem konvensional.

\subsection{Kendala-kendala dalam Mewujudkan Keberlanjutan Kemitraan \\ 3.3.1 Kendala dari pihak Yayasan Trikaya}

Kendala yang dihadapi Yayasan Trikaya dalam melaksanakan kemitraan yaitu belum optimalnya yayasan dapat menampung hasil produksi petani dikarenakan terbatasnya anggaran danterbatasnya sarana prasarana yang dimiliki oleh yayasan sehingga hasil produksi petani belum dapat dipasarkan secara maksimal.

\subsubsection{Kendala dari pihak Subak Purnajaya}

Kendala yang dihadapi petani Subak Purnajaya yaitu sulitnya mencari tukang tebas ketika panen raya sehingga memperlambat petani dalam proses panen dan masih ketergantungan terhadap yayasan dikarenakan petani membutuhkan proses atau waktu untuk menjadi mandiri.

\section{Simpulan dan Saran}

\subsection{Simpulan}

Berdasarkan hasil penelitian dan pembahasan, maka dapat disimpulkan sebagai berikut.

1. Karakteristik Subak Purnajaya sebelum dilaksanakan kemitraan yaitu keterbatasan ilmu yang dimiliki oleh petani dan subak masih menerapkan sistem pertanian konvensional, serta kondisi atau struktur tanah subak memiliki derajat kemasaman yang tinggi yaitu 4,0 sehingga menghambat pertumbuhan tanaman dan berdampak kepada produksi yang menjadi rendah.

2. Kemitraan yang diterapkan dalam pengembangan dan peningkatan produktivitas serta pemasaran hasil pertanian di Subak Purnajaya, Desa Lebih, Kecamatan Gianyar, Kabupaten Gianyar adalah pola Kerjasama Operasional Agribisnis (KOA), petani mitra berperan menyediakan tenaga kerja dan lahan untuk usahatani mereka, sedangkan yayasan bertanggung jawab atas penyediaan modal usahatani berupa sarana produksi, memberikan penyuluhan serta pendampingan, membeli hasil produksi dan juga berperan sebagai penjamin pemasaran hasil produksi petani. Penerapan pola KOA ini membuktikan bahwa dengan sistem pertanian organik rata-rata pendapatan yang diperoleh petani Subak Purnajaya dalam satu musim tanam mencapai Rp. 10.334.960,00, sedangkan pendapatan petani saat sistem konvensional sebesar Rp. 3.361.169,00 dengan rata-rata luas lahan 35,67 are, sehingga terlihat bahwa dengan adanya kemitraan yang terjalin antara yayasan dan subak saat menerapkan pertanian organik petani lebih mendapatkan keuntungan dibandingkan dengan menerapkan sistem konvensional.

3. Kendala-kendala yang dihadapi dalam mewujudkan keberlanjutan kemitraan yaitu belum optimal menampung hasil produksi petani dan terbatasnya sarana prasarana yang dimiliki, hal tersebut merupakan kendala yang harus dihadapi oleh Yayasan 
Trikaya dan kendala yang harus dihadapi petani Subak Purnajaya yaitu sulitnya mencari tukang tebas ketika panen raya dan masih ketergantungan terhadap yayasan.

\subsection{Saran}

Saran yang dapat diberikan sebagai berikut.

1. Bagi Yayasan Trikaya agar memanfaatkan peran media sosial untuk menjangkau pangsa pasar yang lebih luas, sehingga dapat mengoptimalkan pemasaran hasil produksi kepada masyarakat dan memperbaiki sistem manajemen dalam menjalin kemitraan supaya salah satu pihak tidak ada yang merasa dirugikan.

2. Bagi Subak Purnajaya agar dapat memaksimalkan fungsi teknologi untuk mengatasi keterbatasan sumberdaya manusia yang ada, karena dengan adanya bantuan teknologi maka dapat membantu mempermudah pekerjaan di lapangan. Petani juga sebaiknya tetap melanjutkan pertanian sistem organik dengan modal ilmu yang telah diberikan oleh pihak Yayasan Trikaya melalui pendampingan yang pernah dilakukan, karena melihat hasilnya bahwa dengan pertanian organik lebih menguntungkan dibandingkan dengan menggunakan sistem konvensional.

3. Bagi pihak Subak Purnajaya dan Yayasan Trikaya agar mentaati segala aturan yang telah disepakati bersama dan membuatkan sanksi ketika kedua belah pihak tidak mentaati aturan tersebut, sehingga ada kepastian hukum yang mengikat dalam kemitraan.

\section{Ucapan Terimakasih}

Ucapan terimakasih penulis tujukan kepada seluruh pihakyang telah membantu penulis dalam memberikan informasi mengenai penelitian ini sehingga dapat dipublikasikan dalam e-jurnal.

\section{Daftar Pustaka}

Antara, Made. 2014. Format dan Subtansi Proposal Penelitian: Bahan Kuliah Metode Penelitian Sosial Ekonomi. Denpasar. Program Studi Agribisnis Fakultas Pertanian Universitas Udayana.

Badan Pusat Statistik. 2014. Tabel luas panen-produktivitas-produksi tanaman padi seluruh provinsi. Jakarta (ID): Badan Pusat Statistik.

Badan Pusat Statistik Provinsi Bali. 2017. Luas Panen, Rata-Rata Produksi, dan Produksi Padi Sawah dan Padi Ladang Menurut Kabupaten/Kota di Bali, Sensus Pertanian 2017. Internet. [Artikel_online]. https://bali.bps.go.id/statictable/2017/11/06/26/luas-panen-rata-rata-produksi-danproduksi-padi-sawah-dan-padi-ladang-menurut-kabupaten-kota-di-bali-tahun2017.html. Diakses pada tanggal 2 Februari 2018.

Dinas Pertanian Provinsi Bali. 2013. Laporan Pelaksanaan Penyaluran Subsidi Pupuk Organik Tahun 2013. Denpasar.Dinas Pertanian Provinsi Bali.

Ibrahim, M. A. 2015. Metodelogi Penelitian Kualitatif. Bandung. Alfabeta.

Soekartawi. 2002. Analisis Usahatani. Jakarta. Universitas Indonesia.

Sumanto. 1990. Metodologi Penelitian Sosial dan Pendidikan. Yogyakarta. Andi offset. Sumardjo, J.S. dan Wahyu A. 2004. Teori dan Praktek Kemitraan Agribisnis. Jakarta. Penebar Swadaya. 
Widyantara, Wayan. 2015.Modul Mata Kuliah Manajemen Usahatani. Denpasar. Universitas Udayana.

Windia, Wayan. 2006. Transformasi Sistem Irigasi Subak yang Berlandaskan Konsep Tri Hita Karana. Denpasar. Pustaka Bali Post. 